\title{
Guidelines of Funeral Welfare Management for the Elders in the Muslim Way, Kayohmati Community, Bajo District, NARATHIWAT Province
}

\author{
Jirachaya Jeawkok ${ }^{1}$, Sawat Laipaporn ${ }^{2}$, Nawapon Kewsuwun ${ }^{3}$, Abdulkhalig Arrahimee ${ }^{4}$ \\ 1,2,3,4 Faculty of Humanities and Social Sciences, Prince of Songkla University, Pattani 94000, Thailand \\ 1 jirachaya.j@psu.ac.th, ${ }^{2}$ sawat.1@psu.ac.th, ${ }^{3}$ nawapon.k@psu.ac.th , ${ }^{4}$ apdunkoled.c@psu.ac.th
}

\begin{abstract}
This study aims to analyse the funeral welfare for the Muslim elders and to suggest guidelines regarding the funeral welfare management for the Muslim elders. The guidelines might help stakeholders to investigate and manage the welfare more effective and stable through participatory process. Further, this would help the group to get more members which would lead to a quality and sustainable funeral welfare for Muslim elders in the Kayohmati community.The design of this study is mixed method. First, the researchers employed phenomenological research to explore the community's life experience for the primary data. The researchers investigated the meaningful aspects and understandings through conversations, in-depth interviews, focus-group interviews, and questionnaires. The researchers used content synthesis to form guidelines of the funeral welfare management, which was classifying and categorizing topics and arranging concepts. The qualitative data was carefully reconfirmed, and the quantitative data was analysed into frequency, average, and percentage. Moreover, to conduct the research professionally the researchers followed research ethics firmly and this research had been approved for research ethics code of conduct.

The findings regarding needs of the funeral welfare were as follows: the elder members who are low-income need career workshops to support their finance. Furthermore, it was found that community leader plays a key role in facilitating and encouraging collaboration among the community, government, and academic sectors to form public policy. Therefore, the government sector should collaborate with the community which the people could express their performance and self-autonomy and the findings confirmed that we can develop it to public policy and guidelines for the welfare founders, committees, and members to improve the welfare's management system. Also, there could be guidelines to increase medical welfare and income for the elders. The novelty or originality of this studyproposed the funeral welfare management model is getting from the management of Muslim welfare that is sustainable and fit with the local context, religion, knowledge, self-value, and belief in a particular area
\end{abstract}

Keywords

Funeral welfare management, Muslim elders, Kayohmati community, Bajo district, Narathiwat province

Article Received: 10 August 2020, Revised: 25 October 2020, Accepted: 18 November 2020

\section{Introduction}

In the past, Thai people had a life span of around 50 years, yet in the present, it is 73 years and it will be expanding to 80 years in the future. The death rate of Thai people is 400,000 per year and continues rising. In the next 20-30 years, it will be increasing to 600,000 per year which implies that the Thai population number will be stable. (National Statistical Office, 2017; White, 1982) In 2559, there were 10 percent or 9 million 65's year's old elders in Thailand and it was increasing continuously. This shows a rapid change in the elder population. According to several Thai populations between $2558-2573$, Thailand is becoming an aged society, and, in the future, it will be a completed aged society. This change portrays the future image of Thailand, additionally, a key concern goes to how the elders should be taken care of. The elders should earn basic rights according to the Act on the Elderly B.E. 2556, section 11 as "the elderly have rights to get medical supports and services conveniently and fast".

The case of death, there is 2,000-baht bath funeral support for low-income elders. This support could be redeemed within 30 days after the dead announced. (Ministry of Social Development and Human Security, 2016)

Regarding the Southern region context, Narathiwat province has 83,671 elders in 60's years and it is in a status of ageing society. The province gets funeral support from the government but in some districts, for example, Maung,
Yeengo, and Bajo form funeral welfares for their people which are Chareekatmetee, Nawat, and Mueningkandiinya. In Bajo district, there are 4,449 elders which are 8.96 percent of 49,611 members. The Kayomati community established a funeral welfare fund for elders who have lowincome, therefore, those elders could access a full function of the funeral according to the Muslim culture. Moreover, the welfare fund sets the terms in joining which are the prospects should 1) be 60 years or older and 2) not be government officers. Each member will earn 10,000 baht for the funeral expense including bathing, wrapping, praying, carrying, and burying the deceased. This welfare fund offers benefits more than the governments and people in the community trust in the management system which leads to an increase of the welfare fund member.

The researchers, government sector, and community agreed that a manager of the welfare fund was selected by the government sector who have a certain period in the position. When the manager is not in the position, there will be delays in having the new manager and financial and accounting management. It will cause insecurity and instability within the community. All the mentioned stakeholders brainstormed and suggested guidelines to maintain and improve the welfare sustainably.

Research Objectives 
The objectives of this research were to: (1) analyze the funeral welfare fund for the elderly in the Muslim Way in Kayohmati community, Bajo district, Narathiwat province, and (2) to suggest guidelines to improve the funeral welfare management.

\section{Literature Review}

In this study of Development Practices to Welfare Funeral Management for the Elderly in the Muslim Way in Kayohmati community, Bajo district, Narathiwat province, the researchers reviewed related documents and research articles of Muslim funeral management, fund management, participatory concepts, and syarikatmati principles to conduct the research thoroughly and to suggest guidelines to improve the welfare based on the community as follows:

\section{(A)muslim funeral concepts}

Steps of Muslim funeral includes bathing, wrapping, praying, and burying. It is believed that the steps should be provided to those who deceased for the community's sake. The following details are for each step.

2.1 Bathing refers to cleaning the corpse by Muslims who are well-trained. In case of the deceased was male, the ceremony takes place in a men's mosque and male family members could bath the corpse. In this case the deceased was female, the ceremony takes place at a women's mosque. Female members could perform the bathing. Also, there is a controversial issue on a wife bathes a husband which some people do not agree but some do (Muhamud, 2010).

2.2 Wrapping is to use 3-layer white cloth to wrap the body. Each layer is powdered with incense. The expense must be acquired from the deceased's asset, heir, or Muslim welfare (Muhamud, 2010). Moreover, there is Yanaza prayer which happens after wrapping the body, then saying the prayer. The rules for saying Yanaza prayer is the deceased must be Muslim only and it should be placed in front of the praying person even the corpse is buried. The more people participate in the funeral, the more benefits a mosque will get (Muhamud, 2010).

2.3 Burying includes digging, delivering, and burying. To dig a grave, it should be fit with the body then wooden planks are placed to secure the corpse. To deliver the body, Muslims will walk from home to a praying area or a cemetery. Walking from home to a cemetery is the best way to deliver. People who are in the delivery must be quiet. Incense, prayer, music is not allowed. The followers could walk in front or aside yet walking after the body is recommended. To bury, the corpse must be secure by wooden planks and the grave should be deep enough. It is allowed to bury more than 1 body in a grave which is a man, a boy, a woman, and a girl respectively by putting a man's body in Kibla way then bury a woman's body. If those bodies are not in coffins, they have to separate by wooden planks. Male members are preferred to bury the deceased (Muhamud, 2010).

Besides, Islam encourages people to visit the deceased's family for giving mental supports and allows the family to be in mourning by having 3 days off except a wife must be in mourning for 4 months and 10 days. If the wife is expecting, she should be in mourning until delivery. To be in mourning, people can wear normal clothes but cannot be moaning nor hurting themselves (Abdullor, 2019). To carrying out a funeral regarding Islam, there are 4 principles which are bathing, wrapping, praying, and burying.

Table 1 Expenses on Islamic funeral

\begin{tabular}{|c|c|c|}
\hline Ceremony & Tools & Prices \\
\hline $\begin{array}{l}\text { Bathing a } \\
\text { copse }\end{array}$ & 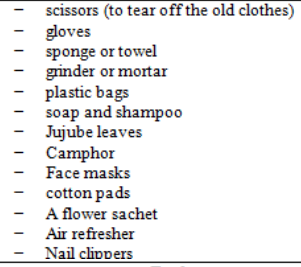 & $\begin{array}{l}-42 \text { baht } \\
-16 \text { baht } \\
-85 \text { baht } \\
-150 \text { baht } \\
-35 \text { baht } \\
-50 \text { baht } \\
- \text { From the community } \\
-20 \text { baht } \\
-120 \text { baht } \\
-250 \text { baht } \\
-125 \text { baht } \\
-25 \text { baht } \\
-25 \text { baht }\end{array}$ \\
\hline Ceremony & Tools & Prices \\
\hline $\begin{array}{c}\text { Wrapping a } \\
\text { coppse }\end{array}$ & $\begin{array}{ll} & \text { White cloth } \\
- & \text { Cotton pads } \\
- & \text { Bomeol flakes } \\
\end{array}$ & $\begin{array}{l}-600 \text { baht } \\
-400 \text { baht } \\
-60 \text { baht }\end{array}$ \\
\hline $\begin{array}{l}\text { Praying to a } \\
\text { corpse }\end{array}$ & $\begin{array}{l}\text { - Cash for people who come to pray } \\
\text { - Religion leader's expense }\end{array}$ & $\begin{array}{l}-40 \text { baht per person (minimum) } \\
-100 \text { baht perperson }\end{array}$ \\
\hline $\begin{array}{l}\text { Burying a } \\
\text { coppse }\end{array}$ & $\begin{array}{ll}- & \text { digging service } \\
- & \text { A coffin } \\
- & \text { Transportation }\end{array}$ & $\begin{array}{l}-600 \text { baht } \\
-\quad 800 \text { baht } \\
-200 \text { baht }\end{array}$ \\
\hline & $\begin{array}{l}\text { Total } \\
\end{array}$ & 12,603 baht \\
\hline
\end{tabular}

Source: (Tohsoh, personal communication, November 18, 2017)

\section{(B)fund concepts}

The researchers introduced concepts of a village and urban community fund and process as follows:

"village and urban community fund" been established to be a source of financial support for people in a community. The fund enhances collaboration among members, moreover, it employs systematic processes which are a unit of management and promotion for borrowers and a unit of procedure of a borrower. To establish the fund, there are 3 principles which are (1) readiness of the village or urban community (2) Revolving fund management in a community, and (3) Assessment and evaluation (Bureau of Educational Standards, 2002; Chareonwisarn, 2008). According to the document analysis, a concept of village fund is based on poverty, inequality, accessibility, distribution of finance, and investment provided by the government. Consequently, low-income people turn to set their revolving fund system. The first local financial institution was established in 1965 at Lamplaimat district, Buriram province. Christians also had Credit Union in Bangkok at Dindang and Huakwang area and this institute is expanded to the urban community. In 1974, a savings group for production had been set by the government also many financial institutes had been set by locals and supported the government.

In the south of Thailand, the fund concept was employed in 1980 by the Keereewong savings group and Namkwao savings group, Songkla province. In 1982, a savings group of Klongpia subdistrict, Jana district, Songkla province was established. In 2015, the fisherman fund of Pakbang village, Jana district, Songkla province was set. In B.E. 2530, the Sakat fund of kwantoh, Satul province was established. The aforementioned was set up by its local wisdom elites. In 1989, the community bank was established by King Rama 9 cooperating with Kasetsart University. The community bank aims to encourage low-income people to save up money and 
provide financial products (Chareonwisarn, 2008; Noisanree, 2007; Office of the National Village and Urban Community Fund, 2020; Wajasit, 2003; Wannapira, 2017; Cohen \& Norman, 1980; Dumas, 1991). This bank could improve people's lives by decreasing expenses, increasing investment opportunities, and providing learning resources. The village and urban community fund concept aim to enhance self-autonomy, therefore, members of a community will be able to manage, evaluate, make decisions, and work together. The community would have a strong financial institute where their members can participate and collaborate. There are 6 purposes of having a community fund (Village and Urban Community Fund Office, 2020):

(1) to build up a strong, transparent, and effective management community fund;

(2) to have the fund as a tool for solving problems and making decisions;

(3) to have a revolving fund for the members to invest or to save up;

(4.) to have the members deposit and get loans from other financial sources

(5.) To give loans to another village fund

(6.) to improve the members' life quality, security, and welfare.

\section{(C)PARTICIPATION}

With Participation refers to being a part of the decisionmaking process but it should be done along with working. Moreover, the 9th National Economic and Social Development plan highlight participation such as participation of people in contributing plans and brainstorming 20-year visions. Further, participation provides people opportunities to explore, plan, and set which can be followed up and evaluated. This goes in line with Ervin (1976) (Cohen \&Uphoff, 1977) that participatory is to have people incorporate to make decisions for their community and employ proper technology to support. Gustavo (2014) states that participation is to have a part of an activity and it associates with individual responsibility or change process. Whang (1981) mentions that participation is a working process of individual or group which reflect the interest or support an institute/system. Moreover, UNISEF (1982) says that participation is self-confidence, freedom, and the community participation. A project would be successful if it is run by a community.

To conclude, participation refers to a group of people or organization runs an activity by brainstorming, planning, collaborating, following up, evaluating, and developing. The people would earn benefits such as exploring their community, exchanging ideas, solving problems, and being responsible.

Regarding this study, participation relates to the welfare of the Kayamati community, for instance, members participate in joining, planning, and working together with voluntary.

\section{(D)SYARIKATMATI CONCEPTS}

Syarikatmati refers to funeral welfare for people who are not members of the community funds. The expenses would be paid when there are dead. The founder was $\mathrm{Mr}$. MahamasakueriTaemamu. There are 700 members. Terms in joining the welfare are 1) paying 300 baths for being a member 2) the investment expense is deducted from the elderly fund for 20 baths when there are dead announced and 3) the payment for each funeral is 10,000 baths.

The concept intends to help low-income families. This help has followed the religion's principles regarding financial supports because Islam mentions that if there is a deceased in a community, the funeral must be arranged immediately. The funeral expense is expensive so being a member of the funeral welfare makes the deceased's family feel secure. This leads to good mental health which is a factor of a good quality of life. According to Islam, having funeral welfare means a great help since it is important to manage the ceremony. The cost of the ceremony is high so it would be better if the deceased's family could get financial support from the community welfare (Taecharin, 2016).

Consequently, to provide good welfare is not only the government's responsibility but also Muslims' which they could help each other to protect, support, and encourage. Syarikatmati in Islam refers to helping a low-income family regarding funeral expenses.

\section{Research Scope On Welfare Funeral Management}

This study: Development Practices to Welfare Funeral Management for the Elderly in the Muslim Way in Kayohmati community, Bajo district, Narathiwat province, the researchers set the scope as follows:

(1.) Content This study aims to explore guidelines in developing the funeral welfare management for the elderly in the Muslim ways, Kayohmati community, Bajo district, Narathiwat province.

(2.) Population and sample group

(2.1) The population was 713 members which were 1.700 active members 2.12 committees ( 2 per village, 6 villages) 3.1 founder.

(2.2) A sample group was 263 members by using Taro Yamane table (Yamane, 1973; Podhisita, 2017)

(3.) The area was Kayohmati community, Bajo district, Narathiwat province,

(4.) The duration was from August - December 2017

\section{Methodology}

The study employs a research-based Development design which aims to analyse current context and problem and suggest guidelines (Boonprasaert, 2016) as follows:

\section{Procedure For Data Collection And Analysis}

The researchers collected 2 types of data which are document analysis and field trip.

(1) Document analysis refers to reviewing related documents and research, recording the data, classifying, categorizing ideas. The findings from this phase have been used to create research instruments and interview guidelines. The researchers cooperated with the welfare and stakeholders for a field trip.

(2) Field trip the researchers collected data at the specific area and used the instruments which are 
(2.1) Questionnaire It was created based on fund concept, participation, syarikatmati, welfare management. It consists of 5 sections which are 1) general information 2) survey on community welfare 3) participation of the community regarding welfare management 4) Syarikatmati and welfare management and 5) suggestions.

(2.2) In-depth interview and focus-group interview They are to study participation in welfare management. The aspects in the interview were developed based on related document and research which are 1) Ways of life 2) Local context, mindset 3 ) getting supports from the welfare 4) the funeral welfare management and 5) guidelines to improving the welfare

The researchers followed the research ethics code of conduct in every phase of the study to ensure all key informants regarding personal information.

To analyze the data, the researchers conducted as follow:

(1.) Questionnaires They were coded and analyzed as

(1.1) Personal information data was analyzed as frequency, average, and percentage.

(1.2) Participation data was analyzed as average and SD.

(2.) Interview forms to collect data, it was divided into 3 types Appleton (1995): 1. Analytic Induction 2. Typological Analysis and 3. Constant Comparison (Wongrattana, 2010) as

(2.1) Reconfirming the information with the sample group regarding the 5 aspects.

(2.2) Classifying the data by transcription then categorizing all the data systematically (Jongwuthiwet, 2010).

According to the procedure for data collection and analysis, it could be concluded as in Figure 1.

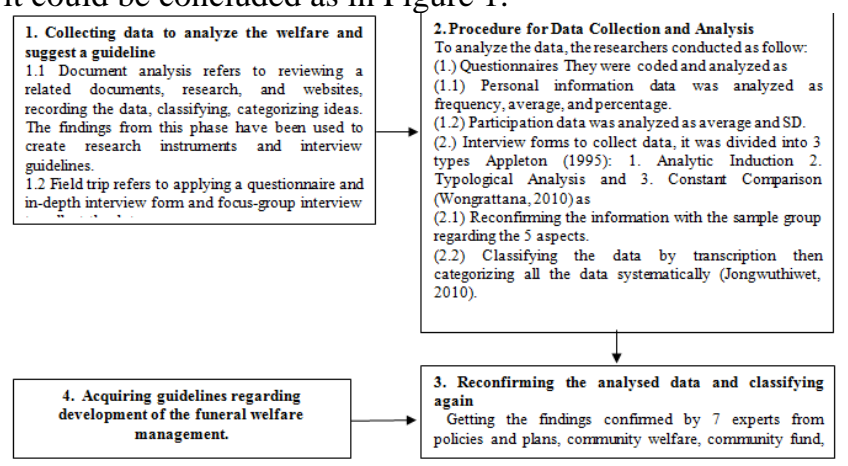

Figure 1: Diagram Of Procedure For Data Collection And Analysis Of Development Practices To Welfare Funeral

Management For The Elderly In The Muslim Way In The

Kayohmati Community, Bajo District, Narathiwat Province. SOURCE: (AUTHORS ' ANALYZED AND DESIGN)

\section{Results And Discussion}

The results and discussion of the study are as follows:

\section{(1) The Analysis Of The Funeral Welfare Management For Elderly}

(1.1) According to the questionnaire, the elderly aged between 60-65 years old and 66-70 years old respectively. 25.60 percent was female and 57.90 percent was male. 50.8 percent completed the primary school level. 91.3 percent were bakers, craftsmen, and farmers. 28.3 percent were
Muslim. 100 percent was low-income and 81.5 percent earned 3,000 baths a month.

(1.2) The overall satisfaction of welfare management was at a high level (4.24). The item of "Having the welfare for helping temporary job members" was at the highest level (4.57) and "Participation in the welfare" was at the lowest level (3.88).

(1.3) The overall satisfaction of participation in welfare management was at a moderate level (2.91). The item of "being participated in planning" was at 3.20 and "being participated in the village representative" was at 2.62.

(1.4) The overall satisfaction of participation in the working process was at a moderate level (3.00). The item of "participating inactivity" was at 3.18 and "participating in budget support was at 2.87 .

(1.5) The overall satisfaction of participation in earning the welfare benefits was at a moderate level (3.12). The item of "earning proper budget in arranging the funeral" was at 3.64 and "earning other fringe benefits from the welfare" was at 2.31 .

(1.6) The overall satisfaction of participation in following up and evaluation was at a moderate level (2.82). The item of "participating in following up and evaluation of the budget management" was at 2.92 and "participating in following up and evaluation of the welfare's successfulness" was at 2.78 . (1.7) The overall satisfaction of syarikatmati and the welfare management was at a moderate level (2.54). "Syarikatmati concept was perceived as important" was at 4.41 and "Do not follow the Islamic rules would lead to negative effects" was at 1.56 .

(1.8) The overall satisfaction of guidelines in developing the welfare was at a moderate level (2.96). The item of "The members need medical welfare to be increased" was at 4.39 and "The member needs the mosque to collaborate in running the welfare" was at 1.63 .

People in the community is Muslim. All the elderly attends religious ceremonies every week. They are farmers. The local wisdom elites are good at many aspects such as crafting, child delivery, bone treatment, fortune-telling, politics, and social sciences, and management. Further, they work with the funeral welfare.

The welfare provides a budget on funeral ceremonies to members. The member will pay 300 baths bath first for their budget and the welfare will collect 20 baht each time when there is the dead announced which relates to the research of Jeawkok (2019). On Syarikatmati: a case study of the Kuwa community, Su-ngaiPadi district, Narathiwat province. It was found that the fund aimed to help low-income members regarding funeral ceremony expenses. The budget collected 120 baths bath once a year from January to March. The deceased family would get 1,000 baths bath. In the case of a non-member, a mosque would take responsibility. The fund consisted of 9 committees and they were volunteers. The money had deposited at an Islamic bank. The committees and the members attended every meeting together to brainstorm, make decisions, follow up, and evaluate. (Jeawkok, 2019; Hangkasee, 2018; Community Development Institute, 2015; College of Islamic Studies, 2015) also mentions that participatory research led to practical solutions since people in a community could share and participate in finding solutions for their community. 


\section{(2) Proposing Guidelines In Improving The Welfare Management}

According to the proposed guidelines, an additional concern was a medical expense. This relates to a study from Kama (2009) and Puri (2004). on Syarikatmati: a case study of Baan Wang community, Wang district, Narathiwat province. It was found that the community had funeral welfare and elderly fund. There were 259 members. The members would get 500 baths twice a year for medical support and 3,500 baths for decreasing (Parinyasutinun, 2016; Kamput, 2015). The researchers introduced medical support and career support to the community for further projects. For career support, the welfare could help the elderly to continue working by providing tools which go in line with Jeawkok (2017) study. It was found that the Tana community spent some money from the fund to arrange fishing tools at a cheap price for the members. This was a strategy to encourage members to work and earn extra income.

(2.1) In the past, the funeral welfare experienced problems regarding finance which affected the deceased's family. The researchers and the stakeholders brainstormed and collaborated to gather information and form practical guidelines. The community leaders should take the key role in facilitating members and coordinating with stakeholders. Moreover, the government should have the community take part in improving and developing, therefore, people could live their lives effectively.

People in the community are Muslim. All the elderly attends religious ceremonies every week. They are farmers. The local wisdom elites are good at many aspects such as crafting, child delivery, bone treatment, fortune-telling, politics, and social sciences, and management, further, they work with the funeral welfare.

The welfare provides a budget on funeral ceremonies to members. The member will pay 300 baths first for their budget and the welfare will collect 20 baht each time when there is the dead announced. The committees and members will have every meeting together to lessen miscommunication. The 10,000 bath budget is enough for one funeral ceremony which relates to the study of Jeawkok (2019) that a fisherman community in the Andaman Sea had established welfare based on the culture and Islam, moreover, participation from everyone created community welfare.

The researchers analyzed the quantity data and designed guidelines in improving the funeral welfare by employing a participatory concept which everyone could initiate, plan, act, earn, and evaluate. The members would be able to learn many aspects together, take part in planning policy, objectives, and working process, develop activities, and build up a relationship as shown in Figure 2. 


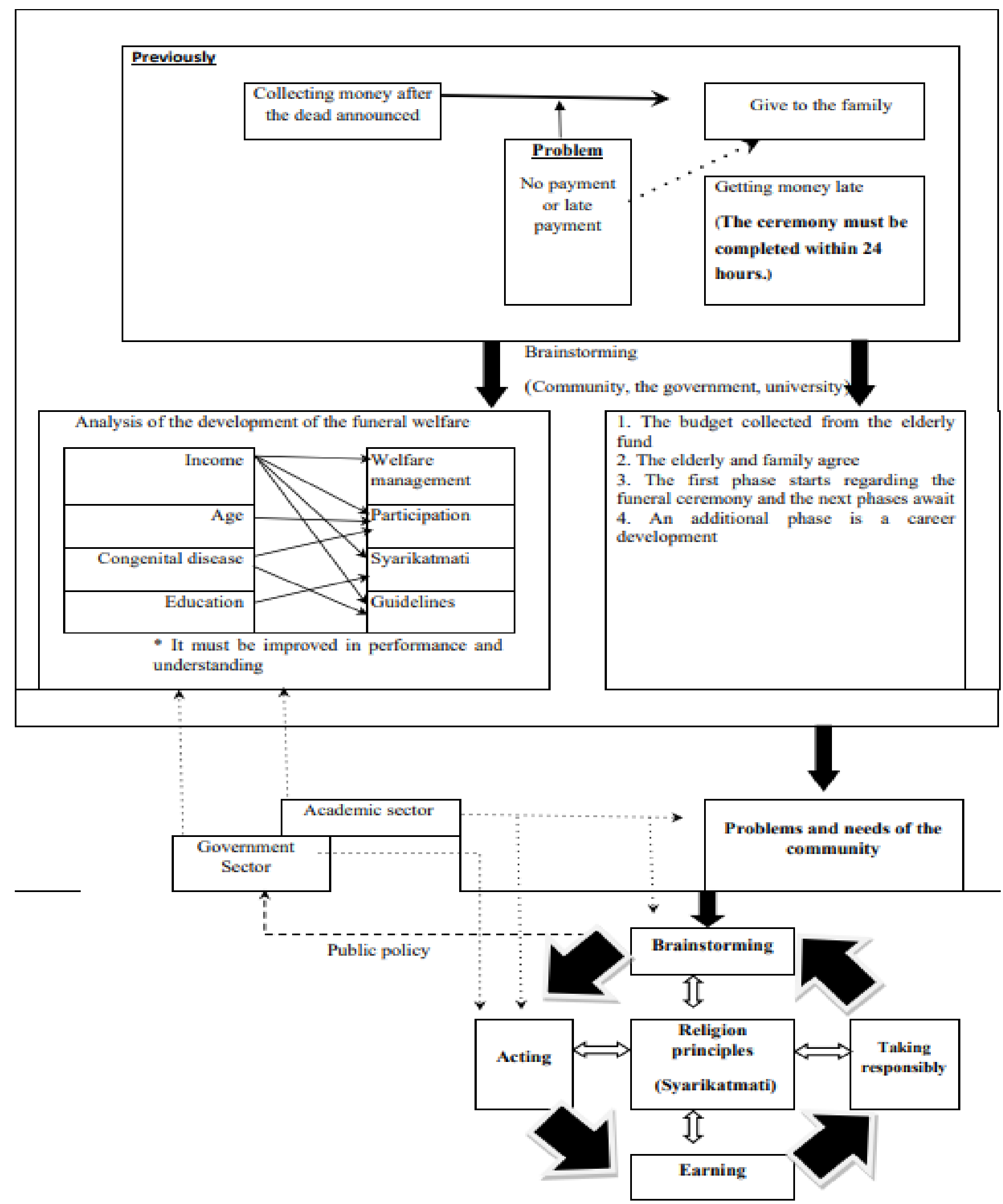

Figure 2 Introducing guidelines in improving the funeral welfare management

Source: (authors ' analyzed and design)

The researchers introduced guidelines in developing the funeral welfare management which is analyzing the welfare, improving the community performance, raising the common understanding regarding income, age, congenital disease, and education which might affect welfare management, participation, and development based on the religion. Then, the researchers took all aspects into account to plan a procedure which is the budget will be collected from the elderly fund, the elderly and family must agree to terms and 
conditions, the welfare runs the funeral ceremony and career development. These would benefit the community and people could follow up and evaluate the welfare performance at the same time. The community leaders should facilitate, encourage, and coordinate stakeholders so it would lead to public policy for long-term management.

\section{Conclusionand Discussion}

According to the study, the discussion is as follows:

1. Analysis of elderly care management in the Kayohmati community

The people in the community are Muslim. Every week on Friday, all the elderly attends the Mosque for Islamic religious lectures. In the Kayohmati community, farmers are mainly the elderly and few of them are contractors. They have two annual festivals in the Kayohmati community: Ashura Day and Moulid Day. The local wisdom elites are good in many fields, such as crafting, child management, bone care, fortune-telling, politics, social sciences, and management, and they also deal with funeral welfare. In addition, they are a part of welfare management that aims to provide members with a budget for funeral ceremonies. The members will pay 300 baht for the first time collecting their budged. The they will be collected 20 baht each time when there is the dead announced which relates to the research of Inda (2012). (Samue, 2015; Keeratinawanun\&Rattanachuay, 2019; Rattanachuay, 2017) on Syarikatmati: a case study of the Kuwa community, Su-ngaiPadi district, Narathiwat province. It was found that the fund targeted to help lowincome members with funeral ceremony expenses. Also, contribute the reward to funeral prayers. Each family will be collected a budget of 120 baht once a year from January to March. The deceased family would get 1,000-bahts. In the case of a non-member, a mosque would take a responsibility for collecting the budget. The fund consisted of 9 committees in which the Islamic priest is the principle assigning the duty to the volunteer team. The money had deposited at an Islamic bank (Keeratinawanun, 2015; Puanghnam, 2019; Spicker, 2017; Sepulveda, 2014).

The committees and members attended every meeting together to brainstorm, make plans, and maintain the coordination of each village's committee for reducing the risk of financial problems (Pinker, 2019; Dixon \&Shik Kim, 2016; Hadley \& Hatch, 2018). Every meeting was attended together by committees and representatives to brainstorm, make arrangements, and maintain the coordination of each village committee to minimize the risk of financial problems also, follow up and evaluate the management plans in order to manage matters properly budget which relates to the research of Cole et al. (2017) and Ronald et al. (2015). that conducts Participatory Action Research for the development community. The purpose of the study is to create, specifically solve community issues, which is the product of the brainstorming of many participants who started from the community to seek for the problems, solutions, and improve together (Marla, 2016; Benjaafar et al. 2018). As well as solving economic issues, politics, and group cooperation (Geir et al., 2018). Besides, to manage a 10,000-bahts welfare budget to assist $\mathrm{g}$ lower-income members in funeral ceremonies to complete the religious provision.
2. Proposing guidelines for improving welfare management in the community of Kayohmati

According to the proposed guidelines, an additional concern was medical expenses. This relates to a study from Rattanachuay (2017) on Syarikatmati: a case study of Baan Wang community, Wang district, Narathiwat province. They are Muslim. It was found that the community had funeral welfare and elderly fund. There were 259 members. This fund began with 72,900 baht, which is deducted as welfare from the elderly allowance of 300 baht. The members would get 500 baths twice a year for medical support and 3,500 baths for decreasing. The result after the proposed guideline to the founder and fund committee found that the way that can lead to improving welfare management for the elder in Kayohmati community, Bacho District, Narathiwat Province as following; First, to increase the welfare of medical support. Also, to promote the job's sales. The proposing welfare management is difficult to improve because the group have difficulties to develop the fund, it takes longer to operate. Thus, the fund aims to help the elder who is the lower-income member increasing medical support which goes in line with Rattanachuay (2017) study, the President of the Subdistrict Administrative Organization (PSAO), mentioned that people in Weang District are Muslim. Their ideological thought base on the Islamic way. In Waeng district also have the Syarikatmati which was a funeral elderly fund and the elder welfare. There are 259 members now. This fund started from 72,900 baht, which was deducted as the welfare from the elderly budget for 300 baht. The members would get 500 baths twice a year for medical assistance and 3,500 baths for decreasing said Rattanachuay (2017). Besides the interesting concrete, this research was honoured by the expert of elder health care, said the president of the Association of the Elderly of Thailand Royal patronage under the Princess Mother's Medical Volunteer Foundation said that the local authorities must take a role in management. The purpose of the fund is to assist the lower-elder members who need the welfare to support their career and create further jobs which relate to the study of Jeawkok (2019) that a fisherman community in the Andaman Sea had established welfare based on the culture and Islam with cooperation among community while The Tamalang group, in the form of Zakat, began to provide welfare. A portion of the money was reserved for purchase of the fishing equipment and sold at the capital price, helping to create community jobs, as well as the Pak Nam community began to provide community by diving profits into the Zakat fund.

\section{Limitation And Study Forward}

The limitations of the study are 1) Area of the study Due to the conflicts in the South of Thailand, we must collect the data as quickly as we could. Some aspects might not be explained in this study. 2) The process of collecting data might delay since the sample group must attend their religious ceremony.

The study forward, we plan to study successful factors of the welfare and follow up the welfare officers' performance on approving medical support (1,000 baht per year) and career support for the elderly. 


\section{Acknowledgement}

With this research article, the researchers would like to thank you for the Thai Health Promotion Foundation for their kind in funding the research of "The project in the participation in social welfare management in the southern border area of Thailand" Annual 2017.

\section{Authors Contribution}

JirachayaJeawkok is responsible for conducted the experimented, analysed the data of the article. SawatLaipaporn is responsible for the conceptual framework and literature review., Nawapon Kewsuwun is responsible for writing, corresponding the paper, discussion, conclusion sections, and approved the final version of the manuscript. AbdulkhaligArrahimee: Responsible for grammar, words checked, discussion, conclusion sections, and planning manuscript outline.

\section{References}

[1] National Statistical Office. (2017). Survey of the elderly population in Thailand. National Statistical Office.

[2] White, A.T. (1982). Why Community Participation a Discussion of the Argument Go the Argument Go Community Participation: Current Issue and Lesson Learned.https://www.ircwash.org/resource s/why-community-participationdiscussion-arguments

[3] Ministry of Social Development and Human Security. (2016). Elderly Affairs. Ministry of Social Development and Human Security.

[4] Cohen, J.M., Uphoff, N.T. (1977). Rural Development Participation: Concept and Measures for Project Design Implementation and Evaluation. https://www.researchgate.net/publication/3 7882394_Rural_Development_Participatio n_Concept_and_Measures_for_Project_De sign_Implementation_and_Evaluation

[5] Muhamud, M. (2010). Basic Islamic Law. Bangkok Islamic Book Centre.

[6] Abdullor, B.A. (2019). The Prayer. World Muslim Youth Council Thailand office.
[7] Bureau of Educational Standards. (2002). Social development services. Ministry of Education.

[8] Chareonwisarn, R. (2008). An evaluation of household wellbeing as impacted by the migration of household members in Songkhla.

https://www.academia.edu/8729365/An_e valuation_of_household_wellbeing_as_an _impact_by_the_migration_of_household_ member_in_Songkhla

[9] Noisanree, W. (2007). The implementation of village fund policy: a case study of Khaochaison subdistrict Khaochaison district Phatthalung province. http://thesis.swu.ac.th/swuthesis/Pub_Pol/ Wannapa_N.pdf

[10] Office of the National Village and Urban Community Fund. (2020). Village and Urban Community Fund Concept. Office of the National Village and Urban Community Fund.

[11] Wajasit, S. (2003). The Elderly Act 2003. http://www.dop.go.th/download/laws/regul ation_th_20160807155130_1.pdf

[12] Wannapira, S. (2017). A study of the implementation of village fund policy: a case study of Nurnperm subdistrict, Nakhonthai district, Phitsanulok province. Srinakharinwirot University.

[13] Cohen, J.M., Norman, T.U. (1980). Participation's Place in Rural Development: Seeking Clarity through Specificity. World Development, 8(3), 213-235. https://doi.org/10.1016/0305750X(80)90011-X

[14] Dumas, C. (1991). Implementing Whole Language: Collaboration, Communication and Coordination. ERIC.

[15] Village and Urban Community Fund Office. (2020). Education and the Family. Allyn and Bacon.

[16] Ervin, W. (1976). Participation Management: Concept Theory and Implementation. ERIC. 
[17] Gustavo, W.C. (2014). The Meaning of Participation in Community Participation. Colombia Habinet.

[18] Whang, I. (1981). Management of Rural Change in Korea: The SammnalUndong. Seoul Nation University Press.

[19] UNISEF. (1982). Popular Participation as a Strategy for Promotion Community Level Action and National Development Report of the Meeting or the Adhoc Group of Experts. New York.

[20] Taecharin, P. (2016). Thai Rural Development. Charoenpon Press.

[21] Yamane, T. (1973). Statistics: An Introductory Analysis. 3rd ed. Harper and Row Publications.

[22] Podhisita, C. (2017). Handbook of the science and art of quality research. Institute for Population and Social Research. Mahidol University Press.

[23] Boonprasaert, U. (2016). Action Research. Office of the Education Council Press.

[24] Appleton. (1995). The effect of a Constructivist of Student Learning During Science Classes Using Constructivist Base Model. Journal of Research in Science Teaching, 19(3), 51-62. https://doi.org/10.1002/(SICI)10982736(199703)34:3<303::AIDTEA6>3.0.CO;2-W

[25] Wongrattana, C. (2010). Techniques for using statistics for research. Srinakharinwirot University Press.

[26] Jongwuthiwet, N. (2010). Strategies, guidelines, and methods for promoting public participation in community development. Saksopa Press.

[27] Jeawkok, J. (2019). Community Welfare: Fund Management of Ban Phong According to Islamic Principles. Journal of Liberal Arts Maejo University, 7(1), 96111. https://so03.tcithaijo.org/index.php/liberalartsjournal/artic le/view/199346/139103

[28] Hangkasee, J. (2018). Concepts of participation theory. Burapha University.
[29] Kama, S. (2009). Analysis of Cooperative Development Guideline to be an Efficient Cooperatives: A Case Study of Ibnu-Affan Savings Cooperatives Ltd. Kasetsart University.

[30] Jeawkok, J. (2017) Fishermen and Social Capital: Community Welfare on the Andaman Coast of Thailand. Journal of Community Development and Life Quality, 6(1), 131-152. https://so02.tcithaijo.org/index.php/JCDLQ/article/view/1 $26517 / 95742$

[31] Puri, E. (2004). Understanding Participation: Theoretical Foundations and Practical Implications. Economic and Political Weekly, 39(24), 2511-2517. https://www.jstor.org/stable/4415152

[32] Parinyasutinun, U. (2016). Community Welfare: Balancing Between Giving and Taking. Journal of Community Development and Life Quality, 4(3), 327336.

[33] Kamput, K. (2015). A critical introduction of modern popular culture: Paradigm of culture and cultural phenomena in Southeast Asia. Journal of Language and Culture, 34(1), 5-28.

[34] Community Development Institute. (2015). Community welfare support project. Community Development Institute.

https://www.slideshare.net/jirateep/255862394365

[35] College of Islamic Studies. (2015). Social welfare in Islam.Prince of Songkla University.

http://www.cis.psu.ac.th/fathoni/lesson/isla mic_society/6.htm

[36] Inda, A.(2012). Zakat:to integrate the overseas communities using the south.Southern Border Civil Society Council.

http://k4ds.psu.ac.th/k4ds_search/pdf/book s/1286.pdf

[37] Samue, A.(2015). Promotion of Zakat For the community welfare of Sakom Subdistrict Administrative Organization, 
Chana District, Songkhla Province. KhonKaen University.

[38] Keeratinawanun, S., \&Rattanachuay, S. (2019). The Mechanisms of Urban Community Welfare in Kamalulislam Masjid Bangkok. Parichart Journal, 32(2), $37-50$. https://www.tcithaijo.org/index.php/parichartjournal/articl e/download/186243/155213/

[39] Rattanachuay, S. (2017). Community Development in Dynamic of New Era. Journals of Politics and Governance, 7(1), 72-87. https://so03.tcithaijo.org/index.php/jopag/article/view/14 7542

[40] Keeratinawanun, S. (2015). The Strength of Community Welfare on Chinese Identity in Case of Bobae. Journals of Politics and Governance, 5(2), 57-71. http://copag.msu.ac.th/journal/filesjournal/ 5-2/19012017242046.pdf

[41] Puanghnam, K. (2019). Community and Local Self-Governance. Borpit Press.

[42] Spicker, P. (2017). Principles of social welfare: an introduction to thinking about the welfare state. Berlin: Democratic Arabic Centre. https://rgurepository.worktribe.com/output/247057/p rinciples-of-social-welfare-anintroduction-to-thinking-about-thewelfare-state

[43] Pinker,R. (2019). The Idea of Welfare. Routledge. https://doi.org/10.4324/9780429057588

[44] Dixon, J., \&Shik Kim, H. (2016). Social Welfare in Asia. Routledge. https://books.google.co.th/books?hl=en\&lr $=\& \mathrm{id}=\mathrm{gLPOC} w A A Q B A J \& o i=$ fnd $\& p g=P$ A1\&dq=social+welfare $+\& o t s=f-$ 0ZIXRSzk\&sig $=0$ Q_-

Flz3pLiIjGJ8A7DtDiOB02w\&redir_esc $=y$ $\# \mathrm{v}=$ onepage $\& \mathrm{q}=$ social $\% 20$ welfare $\& \mathrm{f}=$ fals $\mathrm{e}$

[45] Cole, R., Nikhil, R., Vasilis, G., Kamal, J., Vijay, V., \&Sadra, Y. (2017). Convex Program Duality, Fisher Markets, and
Nash Social Welfare https://dl.acm.org/doi/pdf/10.1145/303327 4.3085109?casa_token $=$ pHOfPUN3EJsA AAAA\%3APnBoTk9L7qSNtqzvxowye9p L-

TB4U7CWhU_6YGtVuX0dh35NOkpvsC 3tjblaHj4PgpvusL6bwQ8

[46] Ronald, K., Gary R., Bradley R., Adam, D., \& James, C. (2015). Stakeholder Agency and Social Welfare: Pluralism and Decision Making in the Multi-Objective Corporation. Academy of Management Review, 41(2), 11-18. https://doi.org/10.5465/amr.2013.0486

[47] Marla, B. W. (2016). Social Work and Social Welfare: An Invitation. Routledge. https://books.google.co.th/books?hl=en\&lr $=\& \mathrm{id}=\mathrm{Fx} 7 \mathrm{NCwAAQBAJ} \&$ oi $=$ fnd $\& p g=P P$ $1 \& \mathrm{dq}=$ social+welfare $+\&$ ots $=108 \mathrm{RyZF}-$ Lj\&sig=3r7Ws7Bv5NdQ9jzi7_OFM3ItW $\mathrm{Bw} \&$ redir_esc $=\mathrm{y} \# \mathrm{v}=\mathrm{onepage} \& \mathrm{q}=\mathrm{socia} \% 2$ 0 welfare $\& \mathrm{f}=$ false

[48] Benjaafar, S., Kong, G., \& Li, X., (2018). Peer-to-Peer Product Sharing: Implications for Ownership, Usage, and Social Welfare in the Sharing Economy. Management Science, 65(2), 459- 465 . https://doi.org/10.1287/mnsc.2017.2970

[49] Geir B., Mitra, T., \&Tungodden, B. (2018). Sustainable Recursive Social Welfare Functions. The Economics of the Global Environment, 29, 165-190. https://doi.org/10.1007/978-3-319-319438_9

[50] Sepulveda, L. (2014). Social Enterprise A New Phenomenon in the Field of Economic and Social Welfare?.Social Policy \& Administration, 49(7), 842-861. https://doi.org/10.1111/spol.12106

[51] Hadley,R., \& Hatch, S. (2018). Social Welfare and the Failure of the State Centralised Social Services and Participatory Alternatives. Routledge. https://doi.org/10.4324/9780429465390 
JirachayaJeawkok, Ph.D.,is Lecturer at Social Development Program, Faculty of Humanities and of Social Sciences, Prince of Songkla University, Thailand. He got a bachelor'sdegree in Nursing Science, a master's degreein Social Development and got a Ph.D. in Human and Social Development, He interesting in Social Sciences and Social work/Development filed.

SawatLaipaporn, Ph.D.,is Lecturer at Social Development Program, Faculty of Humanities and of Social Sciences, Prince of Songkla University, Thailand. He got a bachelor'sdegree in Social Development, a master's degreein Community Development and got a Ph.D. in Rural Resources Development, He interesting in Social Sciences and Sufficiency economyfiled.

Nawapon Kewsuwun, Ph.D., is Lecturer at Information Management Program, Faculty of Humanities and of Social Sciences, Prince of Songkla University, Thailand. He got a bachelor'sdegree in Computer Information systems, a master's degreein Educational Technology and got a Ph.D. in Information Studies, He interesting in Knowledge and Information Management, Educational and Media Technology, Plan and Strategic for the development filed.

AbdulkhaligArrahimee, M.A., is Lecturer at Social Development Program, Faculty of Humanities and of Social Sciences, Prince of Songkla University, Thailand. He got a bachelor'sdegree in Social Development, a master's degreein Human Resources Development and at a present he studies Doctoral degree in Human and Social Development, He interesting in Social Sciences and Social Development filed. 